\title{
P206: Stenotrophomonas maltophilia bacteraemia: analysis of 33 episodes occurred in the ICU at the University Hospital in Sousse-Tunisia
}

\author{
O Bouallègue*, N Jaidane, H Said laatiri, W Naija, S Khefecha Aissa, N Boujaafar, L Dhidah \\ From 2nd International Conference on Prevention and Infection Control (ICPIC 2013) \\ Geneva, Switzerland. 25-28 June 2013
}

\section{Introduction}

Stenotrophomonas maltophilia is a gram negative bacillus that has emerged as an opportunistic pathogen associated with high morbidity and mortality rates.

\section{Objectives}

The aim of this study is to describe the characteristics of bactaeremia due to this strain, their outcome, the antibiotic sensitivity patterns of isolates.

\section{Results}

In our study, $93 \%$ of 33 episodes were nosocomial. There were 22 deaths $(71 \%) 15 \pm 12$ days after the bactaeremia. $17 / 31$ of patients were exposed to broad-spectrum antibiotic specifically imipinem (IMP) before their positive culture. Among cases, 23 (74\%) patient had mechanical ventilation and 29 (93.5\%) had central venous catheterization. Antibiotic susceptibility testing revealed that isolates were most sensitive to Ciprofloxacin (CIP) (84\%), Trimethoprim-sulfamethoxazole (SXT) (71\%) and to Colistin (CS) (58\%). Twenty three percent (23\%) episodes were polymicrobial. A probable portal of entry was identified in $27.3 \%$ of bacteraemic episodes and $57 \%$ were catheter-related. Fifty eight percent (58\%) of the episodes were treated with monotherapy specifically CIP (35\%). Our results were similar to those described by others in the last 20 years. These studies have been mostly retrospective.

\section{Conclusion}

Prevention of S. maltophilia infection relies on the cornerstones of modern infection control, such as higher

Microbiology Laboratory, Department of Hygiene and Service reanimation, Hospital of Sahloul, Sousse, Tunisia emphasis on control of antimicrobial consumption and consideration of environmental reservoirs.

\section{Disclosure of interest}

None declared.

Published: 20 June 2013

doi:10.1186/2047-2994-2-S1-P206

Cite this article as: Bouallègue et al:: P206: Stenotrophomonas maltophilia bacteraemia: analysis of 33 episodes occurred in the ICU at the University Hospital in Sousse-Tunisia. Antimicrobial Resistance and Infection Control 2013 2(Suppl 1):P206.
Submit your next manuscript to BioMed Central and take full advantage of:

- Convenient online submission

- Thorough peer review

- No space constraints or color figure charges

- Immediate publication on acceptance

- Inclusion in PubMed, CAS, Scopus and Google Scholar

- Research which is freely available for redistribution

Submit your manuscript at www.biomedcentral.com/submit
( Biomed Central 